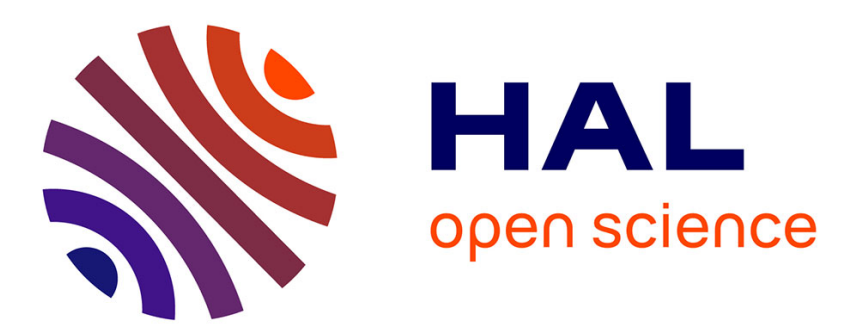

\title{
Recreational phenethylamine poisonings reported to a French poison control center
}

\author{
Gaël Le Roux, Chloé Bruneau, Bénédicte Lelièvre, Marie Bretaudeau \\ Deguigne, Alain Turcant, Patrick Harry, David Boels
}

\section{- To cite this version:}

Gaël Le Roux, Chloé Bruneau, Bénédicte Lelièvre, Marie Bretaudeau Deguigne, Alain Turcant, et al.. Recreational phenethylamine poisonings reported to a French poison control center. Drug and Alcohol Dependence, 2015, 154, pp.46-53. 10.1016/j.drugalcdep.2015.05.048 . hal-02395009

\section{HAL Id: hal-02395009 \\ https://univ-angers.hal.science/hal-02395009}

Submitted on 16 Apr 2020

HAL is a multi-disciplinary open access archive for the deposit and dissemination of scientific research documents, whether they are published or not. The documents may come from teaching and research institutions in France or abroad, or from public or private research centers.
L'archive ouverte pluridisciplinaire HAL, est destinée au dépôt et à la diffusion de documents scientifiques de niveau recherche, publiés ou non, émanant des établissements d'enseignement et de recherche français ou étrangers, des laboratoires publics ou privés. 


\section{Accepted Manuscript}

Title: Recreational Phenethylamine Poisonings Reported To A French Poison Control Center

Author: Gael Le Roux Chloé Bruneau Bénédicte Lelièvre Marie Bretaudeau Deguigne Alain Turcant id="aut0030"

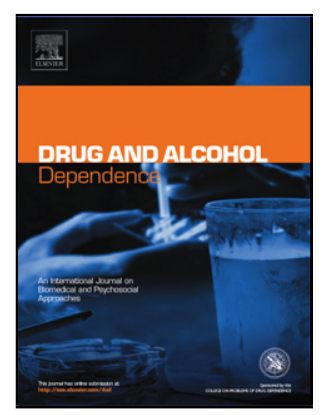
orcid="0000-0002-4694-706X"> Patrick Harry David Boels

PII:

DOI:

Reference:

S0376-8716(15)00357-9

To appear in: $\quad$ Drug and Alcohol Dependence

Received date: $\quad 16-9-2014$

Revised date: 28-5-2015

Accepted date: $\quad 30-5-2015$

Please cite this article as: Le Roux, G., Bruneau, C., Lelièvre, B., Deguigne, M.B., Turcant, A., Harry, P., Boels, D.,Recreational Phenethylamine Poisonings Reported To A French Poison Control Center, Drug and Alcohol Dependence (2015), http://dx.doi.org/10.1016/j.drugalcdep.2015.05.048

This is a PDF file of an unedited manuscript that has been accepted for publication. As a service to our customers we are providing this early version of the manuscript. The manuscript will undergo copyediting, typesetting, and review of the resulting proof before it is published in its final form. Please note that during the production process errors may be discovered which could affect the content, and all legal disclaimers that apply to the journal pertain. 
Recreational Phenethylamine Poisonings Reported To A French Poison Control Center

Gael Le Roux, Chloé Bruneau, Bénédicte Lelièvre, Marie Bretaudeau Deguigne, Alain Turcant, Patrick Harry, David Boels*

\author{
CHU d'Angers \\ Poison Control Center Angers University Hospital \\ Poison Control Center \\ 4 rue larrey \\ Angers, 49933 \\ FRANCE \\ $+33241482121$ \\ daboels@chu-angers.fr
}

*Corresponding Author 


\section{ABSTRACT}

Objectives. Over the last decade, use of phenethylamines has become increasingly prevalent. This study aimed to describe typical aspects of phenethylamine poisoning in order to better inform patient care. Methods. Phenethylamine poisoning cases reported to the Poison Control Center of Angers, France, from January, 2007 to December, 2013 were examined. Clinical findings were examined in 105 patients, including phenethylamine used, symptoms and final outcome. Patients were predominantly male $(80 \%)$, with mean age $26 \pm 8$ years. Results. MDMA (38\%), amphetamine (18\%) and methamphetamine $(14 \%)$ were the most commonly reported. Synthetic cathinones (10\%) and the $2 \mathrm{C}$ series (7\%) were also found. Substances most commonly associated with phenethylamine poisoning were cannabis $(27 \%)$, ethanol $(20 \%)$ and cocaine $(9 \%)$. The most frequently reported symptoms included anxiety and hallucinations (49\%), mydriasis and headache (41\%), tachycardia (40\%) and hypertension (15\%). Complications such as seizures $(7 \%)$, cardiac arrest (5\%), toxic myocarditis (1\%) and hemorrhagic stroke (1\%) were also observed. Of the cases, the Poison Severity Score was: null or low, $66 \%$, moderate, $21 \%$, severe or fatal, $13 \%$. Of the patients, $77 \%$ received hospital care and $12.4 \%$ were admitted to an intensive care unit. Analytical confirmations were obtained for all severe cases. While $93 \%$ of patients recovered, there were 5 deaths and 2 patients presented with neurological sequelae. Conclusions. Phenethylamine poisonings may be severe in young and healthy individuals. Physicians, toxicologists and analysts should be aware of new phenethylamine consumption trends in order to inform management of patient care and to contribute to a more responsive drug policy. 
KEYWORDS: poisoning; phenethylamines; designer drugs; poison control center; amphetamines 


\section{INTRODUCTION}

Designer drugs have become increasingly prevalent among recreational drug users. In particular, amphetamines and MDMA are used across many settings (Guillaume and Pavic, 2011). Besides these substances, a wide variety of new related substances have appeared on the illicit market. Among the 256 new psychoactive substances identified in Europe from 2012 to 2014, 80 were phenethylamines or cathinones. In the same time, members of the French drug abuse monitoring network (Système national d'identification des toxiques et substances, SINTES) have identified 94 new psychoactive substances. In January, 2013, 27 substances in the phenethylamine family (including 15 synthetic cathinones) were circulating in France (Lahaie et al., 2013).

Phenethylamines are a large family of chemical structures that are molecular variants of the core compounds, i.e., amphetamines, MDMA, etc. The phenethylamine skeleton (1) consists of an aromatic ring with a side chain of two carbons ending by an amine group, as shown in Fig. 1. Slight modifications in this structure, partially induced by natural products, can change the pharmacological activity. Phenethylamines may thus undergo two major changes. First, substitution of the alpha carbon by a methyl gives rise to amphetamine derivatives (2), which have an optimal structure for psychostimulant activity (Hill and Thomas, 2011). The $2 \mathrm{C}$ and $\mathrm{D}$ series are obtained by substitutions of the benzene cycle at positions 2 and 5 by methoxy groups and at position 4 by a variable substituent, respectively on phenethylamine (3) or amphetamine (4) (Hill and Thomas, 2011, Maurer, 2010, Shulgin, 1991). These series have tetrahydrobenzodifuranyl and benzodifuranyl analogues (5) called "FLY" (Corazza et al., 2011). Finally, the NBOMe series which groups $\mathrm{N}$-benzyl derivatives of the $2 \mathrm{C}$ series (6) has appeared more recently on the 
drug market (Elz et al., 2002; Heim, 2003). Ring substitutions increase the affinity for 5HT2a receptors, thus providing the hallucinogenic properties (Trachsel, 2012). Specifically, substitution of the aromatic ring by a methylenedioxy group at positions 3 and 4 produces MDMA and derivatives (7). This kind of substitution has given rise to a new pharmacological class called entactogens that express psychostimulant/hallucinogenic properties. Entactogens generally do not cause hallucinations (except at high doses for some of them), but instead promote socialization and a desire for contact with oneself and others (GhyselLaporte et al., 2012; Freudenmann and Spitzer, 2004; Gouzoulis-Mayfrank, 2001). Finally, both methylenedioxyphenethylamines and amphetamines may be substituted by a ketone function on the $\beta$ carbon to lead to cathinones. Synthetic cathinone may have the same structural changes as non-ketonated homologues (Kelly, 2011, Coppola and Mondola, 2012).

The French Poison Control Center (PCC) network is a link in the drug abuse monitoring chain via its emergency call answering and toxicovigilance mission. Calls regarding drug consumption in an addiction context rose by nearly $0.2 \%$ in 2013 . According to the regional health authority (ARS), the prevalence of drug experimentation in the Loire Valley departments in 2010 was approximately $1 \%$ of the general population, somewhat lower than the $3 \%$ recorded throughout France (David et al., 2011).

To our knowledge, no epidemiological data on phenethylamine poisonings has been published by any French PCC. The aim of this investigation was to describe the pattern of exposure to all phenethylamines reported to the Angers PCC, as well as the circumstances under which these poisonings occurred and the consequences. 


\section{METHODS}

This was a retrospective study based on data collected by the Angers PCC during telephone responses to toxicological exposure and during patient follow-up, supplemented by reports from clinical staff in hospital. The Angers PCC manages poisoning cases in western France, which includes around 11 million people and around 30000 calls per year. The proportion of calls from physicians is $61 \%$, compared to $34 \%$ from the general public and $5 \%$ from nurses and paramedics. Data were extracted from the Poison Centers database, authorized by the French data protection authority (Commission Nationale Informatique et Liberté, CNIL, accreditation no. 747735). The personal data of patients were anonymized before studying their medical records. Approval of the local Ethics Committee was unnecessary because of the retrospective and non-interventional design of this study.

The cases were identified through a database search for drugs belonging to the phenethylamine family. Cases between January, 2007 and December, 2013 were included. The substances used, demographic characteristics of the patients (age and gender), poisoning context (date, route of consumption), clinical data regarding the intoxications (symptoms, poisoning severity and final outcome) and care management details were analyzed. A case was defined as exposure to a drug from the phenethylamine family with or without symptoms, according to the patient's own report or after analytical confirmation. Overall poisoning severity was assessed using the Poison Severity Score (Persson et al., 1998) according to the following grades: none (grade 0), minor (grade 1), moderate (grade 2), severe (grade 3) and fatal (grade 4) poisoning. 


\section{RESULTS}

Between January, 2007 and December, 2013, one hundred and five cases of phenethylamine poisoning were recorded. The number of cases increased steadily each year until 2011 and then declined (Fig. 2). A maximum of 10.8/10 000 cases was observed in 2013. Most calls were recorded during weekends and at night. Patient characteristics are shown in Fig. 3. The age of patients ranged from 10 to 60 years, with a mean age of $26 \pm 8$ years (median age: 23 years); most patients were between 15 and 25 years old. A majority of the paitents were male (80\%) for a sex ratio of 4.2. The geographical distribution of cases is shown in Fig. 4.

\subsection{Substances}

All substances consumed are listed in Fig 5. MDMA was the most commonly reported $(\mathrm{n}=40,38 \%)$, followed by amphetamine $(\mathrm{n}=19,18 \%)$ and methamphetamine ( $\mathrm{n}=15,14 \%)$. In some cases, it was impossible to determine the exact substance that was contained in trade name products such as "plant food" or "NRG-3". The oral route was the most common method of exposure to phenethylamines $(n=69,66 \%)$. Nasal or inhaled routes were also used $(n=21$, $20 \%$ ) as well as intravenous routes $(n=10,10 \%)$. Since quantities consumed were difficult to determine via telephone, the exposure dose was unknown in $38(40 \%)$ cases and estimated for $19(18 \%)$ cases. For the other cases, the range was 1 to 5 dosage units or $0.1 \mathrm{mg}$ (MDA) to $7 \mathrm{~g}$ (MDMA). The method of purchase was described for 37 (35\%) cases. Consumers purchased products mainly from friends or during a party in a private setting $(n=10,27 \%)$, via Internet $(n=15,41 \%)$ or in a rave or techno music festival $(n=12,32 \%)$. In one case, the product was purchased from a drug dealer on the street. Substances other than phenethylamines were reported in $60(57 \%)$ of the cases. The most common additional substances were 
alcohol $(n=29,28 \%)$ and cannabis $(n=28,27 \%$ of these exposures). Medical drugs consumed concurrently were cyamemazine, hydroxyzine, zuclopenthixol, trihexyphenidyl and benzodiazepines. In one case, up to 5 different substances (cocaine, heroin, methadone, alcohol, and hallucinogenic mushrooms) were consumed in addition to MDMA.

\subsection{Clinical and laboratory findings}

Clinical findings are listed in Table 1 . For the 45 patients who only consumed a phenethylamine, $32 \%$ of the symptoms reported were psychiatric $(n=32), 21 \%$ were cardiovascular $(n=21)$ and $18 \%$ were described as neurological disorders $(n=18)$. Tachycardia, mydriasis, hallucinations, anxiety, restlessness, mental clouding, high blood pressure, nausea or vomiting, headache and cyanosis were described in more than $10 \%$ of the patients. When a phenethylamine was consumed alone, hypoesthesia was also described in more than $10 \%$ of patients. Seizures were also noted in more than $10 \%$ of patients when other substances were associated with phenethylamines.

Laboratory assay findings of creatine phosphokinase (CPK) and myoglobin were available in $13(12 \%)$ and $5(5 \%)$ cases, respectively. The CPK serum activity was over $1000 \mathrm{IU} / \mathrm{L}$ for 7 patients (median: 1288 [178 - 29 000] IU/L) and myoglobinaemia was systematically higher than normal (median: 226.5 [114 - 353] $\mu \mathrm{g} / \mathrm{L}$ ), which was a sign of rhabdomyolysis. Hepatic transaminase (SGOT/SGPT) activity was increased in 3 cases (from 1942/2365 to 8000/6000 UI/L).

\subsection{Care management}

Patients received hospital care in $77 \%$ of cases $(n=81)$. For 13 of them $(12 \%)$, admission in an intensive care unit was required. Medical supervision was necessary for 63 patients (60\%) and at least a medical consultation was advised for 
19 patients (18\%). Table 2 shows the reported treatments for phenethylamine poisonings.

Toxicologically, the presence of phenethylamines was confirmed by toxicological investigation for $52(49 \%)$ patients. All severe cases were monitored at least by urinary screening. Other toxicology tests are summarized in Fig. 6 .

\subsection{Severity and outome}

Severity of poisoning was scored according to the PSS. The gravity was null or low for $66 \%(n=69)$ of cases, moderate for $21 \%(n=22)$ of cases and severe or fatal for $13 \%(n=14)$ of cases. Severities of exposure per product are summarized in Fig. 5. The number of severe cases was greater in a poly-intoxication context than when the phenethylamine was used alone (10 cases vs. 4 cases). Rapid recovery was noted for $93 \%(n=98)$ of the exposed subjects. Two cases with neurological sequelae were identified. Exposure was associated with death in 5 cases, three of which were the result of multiple drug consumption. The severe cases are described in Table 3.

\subsection{Fatal cases}

Case 1. A 26-year-old woman with a history of cannabis abuse was presumed to have ingested a drug called "speed" at a party. Ten hours later she presented with seizures, bradycardia between 35 and 70 beats/min and hyperthermia $\left(40.8^{\circ} \mathrm{C}\right)$. Her blood pressure was normal at $120 / 40 \mathrm{mmHg}$. Cardiopulmonary arrest occurred rapidly. However, despite initiation of cardiopulmonary resuscitation, the patient died 15 hrs. after drug consumption. The autopsy report established that death was caused by pulmonary inhalation of gastric contents following toxic epilepsy. The amphetamine concentration in the subclavian blood was $1700 \mu \mathrm{g} / \mathrm{L}$, for a lethal dose estimated to be $500 \mu \mathrm{g} / \mathrm{L}$. 
Case 2. A 21-year-old man who attended a party with friends presented with malaise and dyspnea 2 hrs. after methylone ingestion. His friends bathed him in a pool of cold water. Then he presented with convulsions followed by cardiac arrest. Cardiopulmonary resuscitation was initiated by his friend and relayed by the emergency unit. Death was confirmed $2 \mathrm{~h}$ after the drug consumption, following $1 \mathrm{hr}$. of cardiac massage and intubation difficulties due to trismus. The blood methylone concentration was $7660 \mu \mathrm{g} / \mathrm{L}$ (lethal dose: $500 \mu \mathrm{g} / \mathrm{L}$ (Pearson et al., 2012)).

Case 3. This case was declared to the Angers PCC by the toxicology laboratory of the Academic Hospital. No anamnesis could be obtained but the analytical results were as follows: in the urine sample, amphetamine was detected at $1600 \mu \mathrm{g} / \mathrm{L}, \mathrm{MDMA}$ at $83300 \mu \mathrm{g} / \mathrm{L}$ and MDA at $3200 \mu \mathrm{g} / \mathrm{L}$; in the blood sample MDM A was detected at $3300 \mu \mathrm{g} / \mathrm{L}$ and MDA at $160 \mu \mathrm{g} / \mathrm{L}$. It is difficult to determine a lethal dose of MDMA since its toxicity is closely linked to the individual susceptibility.

Case 4. A patient known to be an addicted drug user was found dead in his home. Toxicological analysis revealed cocaine, methadone and hydroxyzine. A urine drug screening was positive for MDMA and the blood sample contained $40 \mu \mathrm{g} / \mathrm{L}$ of MDMA.

Case 5. A 26-year-old man attended a local rock festival where he ingested some "blue pills". When he went to the first-aid post, he suffered from tremors and sweating for $1 \mathrm{hr}$. His clinical condition deteriorated rapidly and he displayed: polypnoea $(60 / \mathrm{min})$, hyperthermia $\left(41^{\circ} \mathrm{C}\right)$, restlessness, cyanosis and vomiting. After 10 min he presented with cardiac arrest resolved by external cardiac massage. The patient has been intubated, ventilated and admitted to an Emergency unit. ECG showed the following abnormalities: tachyarrhythmia, ventricular tachycardia and finally asystole. He was treated by norepinephrine, epinephrine, amiodarone and 
sodium salts. After 2 hours of resuscitation attempts, the patient died. Blood MDMA was detected at $2000 \mu \mathrm{g} / \mathrm{L}$.

\section{DISCUSSION}

This retrospective study presents an original French series of phenethylamine poisoning cases reported to the Angers PCC over a period ranging from January, 2007 to December, 2013. Phenethylamine poisoning was associated with death in 5 patients $(5 \%)$. This mortality rate is higher than other series in which it ranged from 1 to $2.5 \%$ (C.D.C., 2011, Liechti et al., 2005). Admission to an intensive care unit following phenethylamine ingestion is not uncommon, as observed in a Zurich study on MDMA (Liechti et al., 2005). The proportion of patients that require medical consultation after phenethylamine consumption has not yet been reported. The need for medical treatment associated with poisoning due to MDMA appears lower than corresponding medical care for opiates, cocaine or methamphetamine (Liechti et al., 2005). However, it may be greater when all phenethylamines are taken into account. In this study, we grouped phenethylamines together in order to identify the general poisoning pattern (consumption trends, symptoms and management). Typically, patients exposed to phenethylamines were young and male, consistent with other case series (C.D.C., 2011; Forrester, 2012; Wood et al., 2011). Clinical findings were consistent with sympathetic activation. Psychiatric symptoms occurred most frequently, with distress and anxiety being the predominant manifestations. Patients also experienced unpleasant hallucinations, emotional disturbances and frequent agitation. Tachycardia and hypertension were the predominant cardiovascular symptoms. Neurologically, tremors and seizures were also experienced. The literature on phenethylamines sensu largo is sparse (C.D.C., 2011) and generally related to specific products: ecstasy, synthetic cathinones, 25I-NBOMe, etc. 
However, the same clinical profiles are described elsewhere (Liechti et al., 2005; Spiller et al., 2011; Wood et al., 2011; Hill et al., 2013). Phenethylamine users were mainly poly-intoxicated, similar to findings from a US study (Martins et al., 2005), with cocaine, ethanol and cannabis being the most commonly co-ingested substances. Symptoms of alcohol poisoning were paradoxically low despite the reported frequency of alcohol intake. However, it has been shown that subjective alcohol-induced sedation effects are reduced by MDMA, without any improvement of psychomotor performance. Alcohol also likely prolongs the subjective effects of MDMA (Hernandez-Lopez et al., 2002). Another study showed that alcohol tends to reduce hyperthermia induced by MDMA (Mohamed et al., 2011). Cannabis use in combination with phenethylamines is common and often recommended in lay user forums to avoid a bad "come down". Cannabis may also decrease the negative effects of MDMA (e.g., aggressive behaviour or negative symptoms). The combination of cocaine with MDMA is referred to as "cloud mind" or "bumping up" (Mohamed et al., 2011).

Half of the cases were confirmed by laboratory findings of phenethylamine poisoning. Serum and urinary concentrations are hard to interpret and uninformative for determining prognosis. Milroy et al. (2011) reported a series of 77 deaths for which toxicological assays were positive for MDMA, MDEA and MBDB. Concerning deaths due to MDMA consumption, the blood concentration range was between 478 and $53900 \mu \mathrm{g} / \mathrm{L}$ (mean concentration of $8430 \mu \mathrm{g} / \mathrm{L}$ ), while MDMA blood concentrations were $40-41500 \mu \mathrm{g} / \mathrm{L}$ (mean of $2900 \mu \mathrm{g} / \mathrm{L}$ ) when multiple drugs were consumed. These wide ranges should be considered carefully because the quantification of phenethylamines does not necessarily equate with toxicity, highly dependent on individual susceptibility. Wide variations between serum and urine 
concentrations should be considered and may be due to differences in the timing of samples, analytical methods and variations of toxicokinetics among patients.

The products were mainly acquired and used alone or during private parties. This pattern of use reflects the advent of "recreational phenethylamine drugs". The fact that referrals to the Angers PCC were mainly on Saturday evenings, between 8:00 pm and 8:00 am, also reflects this pattern of use. Approximately one quarter of the phenethylamine poisoning cases were from Brittany, where there are many music festivals and free parties, i.e., prime environments for phenethylamine consumption. Many products are purchased online under various names: bath salts, insect repellents, stain removers, plant nutrients, legal cocaine or methamphetamine Spiller et al. (2011). Information gathered on the Internet can conversely motivate a call to a PCC, regarding uncertainty about the drug or its dosage. The precise ingested product is seldom known. In this study, the doses were estimated in at least $60 \%$ of cases due to the efforts of the Angers PCC staff to collect the maximum amount of information from patients or physicians during telephone calls.

The Internet has been a driving force in the increasing development of the market for designer drugs, facilitating the promotion and sale of drugs designated as "research chemicals", "party pills" or "legal highs". In 2011, nearly 30 European French-language commercial websites were selling illicit substances. At the European level, between 2010 and 2012, there was a sharp increase (170 to 693) in the number of websites offering psychostimulant drugs within the European Union (Lahaie et al., 2013). The internet is also an important source of information for drug users. It was reported that eight out of ten times, web searches on MDMA, GHB or "magic mushrooms" guided people to websites selling or promoting the products. Information presented on these websites is uncontrolled and often written by 
consumers themselves. These forums are a important source of peer learning for the youngest drug users. Monitoring the flow of information and drugs trade on the internet should represent a significant part of drug policy, e.g., closure of illegal websites, early identification of new trends on drug chat forums, provision of validated information on product-related risks (Dumestre-Toulet and Verstraete, 2012, Psychonaut Web Mapping Research Group, 2010).

Between 2007 and 2011, the number of phenethylamine poisoning cases increased from 6 to 23. This pattern matches the number of new products that appeared on the European drug market. The number of cases began decreasing in 2011. However, this decline was not significant and several hypotheses have been proposed to explain this trend. Firstly, the use of newer products such as synthetic cannabinoids may have become of greater interest than phenethylamines to those using illicit substances. The use of phenethylamine may also have declined to the reports of bath salts poisoning cases. Another possible explanation is that there may have been a decline in the supply of phenethylamines due to a reduction on raw materials and the addition of synthetic cathinones to the French list of illicit drugs in July 2012. However, we observe a new peak in poisonings in 2013 due to the dynamics of the illicit drug market whereby new synthetic products continually circumvent drug policy. Several limitations should be taken into account in the interpretation of the results. Firstly, there may have been selection bias regarding cases reported to the Angers PCC because their representation among the actual population of phenethylamine users is unknown. Furthermore only the most severe cases are reported since physicians may feel comfortable managing mild cases without the involvement of Angers PCC. Although the coverage of the Angers PCC represents a fifth of the French population, the data presented in this study cannot be 
extrapolated to the national territory. In addition, information conveyed by callers over the phone are sometimes fragmentary and unclear. Furthermore, poisoning cases involving multiple substances are considered to be more severe, requiring further investigations, and there are greater efforts to collect more precise information. For example, comprehensive drug testing was not performed on all subjects and the exact amounts and type of substances reportedly used is therefore not known; some subjects may not have in fact have been exposed to phenethylamines.

In conclusion, phenethylamine poisoning has the potential to be severe. Close collaboration between clinicians, physicians and analytical toxicologists is essential to better manage phenethylamine poisoning cases. Intoxications most commonly affect young subjects between 15 and 25 years of age who can easily obtain products online or through widespread dissemination at both public and private parties. In these settings, knowledge of the danger associated with the use of these products is limited and often trivialized. The results of this first French study should contribute to the implementation of a proactive policy against drug abuse. 


\section{FIGURE CAPTIONS}

Figure 1. Chemical structures of several members of the phenethylamines family of drugs.

Figure 2. Number of phenethylamine poisonings reported to the Angers PCC per year between 2007 and 2013. Data were normalized by the total number of cases per year.

Figure 3. Age and gender of patients intoxicated by phenethylamines as reported to the Angers PCC from 2007 to 2013.

Figure 4. Distribution of phenethylamine poisonings in western France reported to the Angers PCC between 2007 and 2013. The grey scale follows the number of cases per administrative district.

Figure 5. Drugs incriminated and severity of phenethylamine poisonings reported to the Angers PCC from 2007 to 2013. Severity was scored according to the Poison Severity Score as follows: none (PSS 0), minor (PSS 1), moderate (PSS 2), severe (PSS 3) and fatal (PSS 4) poisoning.

Figure 6. Drugs of abuse and other substances screened in phenethylamine poisonings reported to the Angers PCC from 2007 to 2013. 


\section{REFERENCES}

C.D.C., 2011. Emergency department visits after use of a drug sold as "bath salts"-Michigan, November 13, 2010-March 31, 2011. MMWR 60, 624-627.

Coppola, M., Mondola, R., 2012. Synthetic cathinones: chemistry, pharmacology and toxicology of a new class of designer drugs of abuse marketed as "bath salts" or "plant food". Toxicol. Lett. 211, 144-149.

Corazza, O., Schifano, F., Farre, M., Deluca, P., Davey, Z., Torrens, M., Demetrovics, Z., Di Furia, L., Flesland, L., Siemann, H., Skutle, A., Van Der Kreeft, P., Scherbaum, N., 2011. Designer drugs on the internet: a phenomenon out-of-control? the emergence of hallucinogenic drug BromoDragonfly. Curr. Clin. Pharmacol. 6, 125-129.

David, S., Bournot, M.-C., Lelièvre, F., Tallec, A., 2011. Consommation de drogues illicites chez les jeunes des Pays de la Loire. Premiers résultats du Baromètre santé jeunes 2010. Observatoire régional de la santé des Pays de la Loire.

Dumestre-Toulet, V., Verstraete, A., 2012. Chapitre 4 - Toxicologie et Internet. In: KINTZ, P. (ed.) Traité de Toxicologie Médico-Judiciare. Elsevier-Masson, Issy-les-Moulineaux.

Elz, S., Kläs, T., Warnke, U., Pertz, H., 2002. Development of highly potent partial agonists and chiral antagonists as tool for the study of 5-HT2A-receptor mediated function. Naunyn-Schmiedebergs Arch. Pharmacol. R29.

Forrester, M. B., 2012. Synthetic cathinone exposures reported to Texas poison centers. Am. J. Drug Alcohol Abuse 38, 609-615.

Freudenmann, R. W., Spitzer, M., 2004. The Neuropsychopharmacology and Toxicology of 3,4-methylenedioxy-N-ethyl-amphetamine (MDEA). CNS Drug Rev. 10, 89-116. 
Ghysel-Laporte, M.-H., Sibille, P., Milan, N., 2012. Amphétamines et dérivés. In: Kintz, P. (Ed.), Traité de Toxicologie Médicojudiciaire. 2e ed. Elsevier Masson S.A.S., Issy-les-Moulineaux,

Gouzoulis-Mayfrank, E., 2001. Differential actions of an entactogen compared to a stimulant and a hallucinogen in healthy humans. In: Nichols, D. E. (Ed.), The Heffter Review of Psychedelic Research. Heffter Research Institute, Santa Fe.

Guillaume, M., Pavic, G., 2011. Phénomènes émergents liés aux drogues en 2010. Tendances récentes sur le site de Rennes. TREND.

Heim, R., 2003. Synthese und Pharmakologie potenter 5-HT2A-Rezeptoragonisten mit N-2-Methoxybenzyl-Partialstruktur. Freien Universität Berlin.

Hernandez-Lopez, C., Farre, M., Roset, P. N., Menoyo, E., Pizarro, N., Ortuno, J., Torrens, M., Cami, J., De La Torre, R., $2002 . \quad 3,4-$ Methylenedioxymethamphetamine (ecstasy) and alcohol interactions in humans: psychomotor performance, subjective effects, and pharmacokinetics. J. Pharmacol. Exp. Ther. 300, 236-244.

Hill, S. L., Doris, T., Gurung, S., Katebe, S., Lomas, A., Dunn, M., Blain, P., Thomas, S. H. L., 2013. Severe clinical toxicity associated with analytically confirmed recreational use of 25I-NBOMe: case series. Clin. Toxicol. 51, 487-492.

Hill, S. L., Thomas, S. H., 2011. Clinical toxicology of newer recreational drugs. Clin. Toxicol. (Phila.) 49, 705-719.

Kelly, J. P., 2011. Cathinone derivatives: a review of their chemistry, pharmacology and toxicology. Drug Test Anal. 3, 439-453.

Lahaie, E., Martinez, M., Cadet-Taïrou, A., 2013. Nouveaux produits de synthèse et Internet. Tendances n`84. O.F.D.T. 
Liechti, M. E., Kunz, I., Kupferschmidt, H., 2005. Acute medical problems due to Ecstasy use. Case-series of emergency department visits. Swiss Med. Wkly. $135,652-657$.

Martins, S. S., Mazzotti, G., Chilcoat, H. D., 2005. Trends in ecstasy use in the United States from 1995 to 2001: comparison with marijuana users and association with other drug use. Exp. Clin. Psychopharmacol. 13, 244-52.

Maurer, H. H., 2010. Chemistry, pharmacology, and metabolism of emerging drugs of abuse. Ther. Drug Monit. 32, 544-549.

Milroy, C. M., 2011. "Ecstasy" associated deaths: what is a fatal concentration? Analysis of a case series. Forensic Sci. Med. Pathol. 7, 248-252.

Mohamed, W. M., Ben Hamida, S., Cassel, J. C., De Vasconcelos, A. P., Jones, B. C., 2011. MDMA: interactions with other psychoactive drugs. Pharmacol. Biochem. Behav. 99, 759-774.

Pearson, J. M., Hargraves, T. L., Hair, L. S., Massucci, C. J., Frazee, C. C., 3rd,

Garg, U., Pietak, B. R., 2012. Three fatal intoxications due to methylone. J. Anal. Toxicol. 36, 444-451.

Persson, H. E., Sjoberg, G. K., Haines, J. A., Pronczuk De Garbino, J., 1998. Poisoning severity score. Grading of acute poisoning. J. Toxicol. Clin. Toxicol. $36,205-213$.

Psychonaut Web Mapping Research Group, 2010. Psychonaut Web Mapping Project: Final report. Institute of Psychiatry, King's College London, London UK.

Shulgin, A. 1991. Pihkal: A Chemical Love Story. CA, Transform Press, Berkeley. 
Spiller, H. A., Ryan, M. L., Weston, R. G., Jansen, J., 2011. Clinical experience with and analytical confirmation of "bath salts" and "legal highs" (synthetic cathinones) in the United States. Clin. Toxicol. (Phila.) 49, 499-505.

Trachsel, D., 2012. Fluorine in psychedelic phenethylamines. Drug Test Anal. 4, 577-590.

Wood, D. M., Greene, S. L., Dargan, P. I., 2011. Clinical pattern of toxicity associated with the novel synthetic cathinone mephedrone. Emerg. Med. J. $28,280-282$. 


\section{Author disclosures}

\section{Role of funding source}

Nothing declared.

\section{Contributors}

Authors Gaël Le Roux and David Boels designed the study. Authors David Boels, Chloé Bruneau, Marie Bretaudeau-Deguigne and Patrick Harry collected cases of the Emergency Answering Service. Authors Alain Turcant and Bénédicte Lelièvre shared their analytical skills for toxicological investigations. Author Gaël Le Roux wrote drafts of the manuscript, which were subsequently circulated to all authors for their comments, critiques and suggestions. All authors contributed to and approved the final manuscript.

\section{Conflict of interest}

All authors declare that there are no conflicts of interest.

\section{Acknowledgements}

We are very grateful to Dr. Ingrid Blanc-Brisset (Paris PCC) for the help provided on the Poison Center database and to David Manley, a professional native English speaking scientific translator, for correcting the English version of the manuscript. 
Table 1. Symptoms observed in phenethylamine poisonings reported to the Angers PCC between 2007 and 2013.

\begin{tabular}{|c|c|c|c|}
\hline Symptom & $\begin{array}{l}\text { All cases } \\
\text { n (\%) }\end{array}$ & $\begin{array}{l}\text { No other } \\
\text { substances } \\
\text { n }(\%) \\
\end{array}$ & $\begin{array}{l}\text { Associated } \\
\text { substances } \\
\text { n }(\%)\end{array}$ \\
\hline Tachycardia & $42(40)$ & $19(42)$ & $23(38)$ \\
\hline Mydriasis & $30(28)$ & $12(27)$ & $18(30)$ \\
\hline Hallucinations/delirium & $27(26)$ & $11(24)$ & $16(27)$ \\
\hline Fear/anxiety & $24(23)$ & $9(20)$ & $15(25)$ \\
\hline Restnessless/excitement & $22(21)$ & $4(9)$ & $18(30)$ \\
\hline Sleepiness/mental clouding & $16(15)$ & $8(18)$ & $8(13)$ \\
\hline High blood pressure & $16(15)$ & $7(16)$ & $9(15)$ \\
\hline Nausea/vomiting & $14(13)$ & $8(18)$ & $6(10)$ \\
\hline Headache & $13(12)$ & $7(16)$ & $6(10)$ \\
\hline Cyanosis & $11(10)$ & $7(16)$ & $4(7)$ \\
\hline Sleep disorders & $9(9)$ & $4(9)$ & $5(8)$ \\
\hline Hypoesthesia/paresthesia & $8(8)$ & $6(13)$ & $2(3)$ \\
\hline Malaise & $7(7)$ & $4(9)$ & $3(5)$ \\
\hline Seizures & $7(7)$ & $1(2)$ & $6(10)$ \\
\hline Cardiac rhythm trouble & $6(6)$ & $3(7)$ & $3(5)$ \\
\hline Disorientation & $6(6)$ & $2(4)$ & $4(7)$ \\
\hline Excessive sweating & $6(6)$ & $4(9)$ & $2(3)$ \\
\hline Hyperthermia $\left(>38^{\circ} \mathrm{C}\right)$ & $5(5)$ & $4(9)$ & $1(2)$ \\
\hline Localized hypertonia & $5(5)$ & $1(2)$ & $4(7)$ \\
\hline Cardiac arrest & $5(5)$ & $2(4)$ & $3(5)$ \\
\hline Myosis & $5(5)$ & $0(0)$ & $5(8)$ \\
\hline Coma (GSC 9-14) & $5(5)$ & $2(4)$ & $3(5)$ \\
\hline Chills & $5(5)$ & $5(1)$ & $1(2)$ \\
\hline Lower abdominal pain & $4(4)$ & $2(4)$ & $2(3)$ \\
\hline Aspiration pneumonia & $4(4)$ & $1(3)$ & $3(5)$ \\
\hline Chest pain/chest tightness & $4(4)$ & $0(0)$ & $4(7)$ \\
\hline Character disorders & $4(4)$ & $3(7)$ & $1(2)$ \\
\hline Dyspnea & $4(4)$ & $2(4)$ & $2(3)$ \\
\hline Precordial algia & $4(4)$ & $2(4)$ & $2(3)$ \\
\hline Memory issues & $4(4)$ & $2(4)$ & $2(3)$ \\
\hline Euphoria & $3(3)$ & $1(2)$ & $2(3)$ \\
\hline Bradycardia & $3(3)$ & $1(2)$ & $2(3)$ \\
\hline Respiratory acidosis & $3(3)$ & $1(2)$ & $2(3)$ \\
\hline Dizziness & $3(3)$ & $2(4)$ & $1(2)$ \\
\hline Dryness of mucous membranes & $3(3)$ & $1(2)$ & $2(3)$ \\
\hline Acute renal failure & $3(3)$ & $1(0)$ & $2(3)$ \\
\hline Hypothermia below $35^{\circ} \mathrm{C}$ & $3(3)$ & $1(0)$ & $2(3)$ \\
\hline Hepatitis & $3(3)$ & $1(0)$ & $2(3)$ \\
\hline Coma (GSC 4-8) & $3(3)$ & $1(0)$ & $2(3)$ \\
\hline Anuria & $3(3)$ & $1(0)$ & $2(3)$ \\
\hline Low blood pressure & $3(3)$ & $2(4)$ & $1(2)$ \\
\hline Glare & $2(2)$ & $1(2)$ & $1(2)$ \\
\hline Abnormal movements & $2(2)$ & $1(2)$ & $1(2)$ \\
\hline Circulatory shock & $2(2)$ & $1(2)$ & $1(2)$ \\
\hline Erythema/rash & $2(2)$ & $0(0)$ & $2(3)$ \\
\hline Asthenia & $2(2)$ & $0(0)$ & $2(3)$ \\
\hline Apnoea & $2(2)$ & $0(0)$ & $2(3)$ \\
\hline Metabolic acidosis & $2(2)$ & $0(0)$ & $2(3)$ \\
\hline Extremity tremors & $2(2)$ & $0(0)$ & $2(3)$ \\
\hline Acute pulmonary oedema & $2(2)$ & $1(2)$ & $1(2)$ \\
\hline Heart failure & $2(2)$ & $1(2)$ & $1(2)$ \\
\hline Dehydration & $2(2)$ & $1(2)$ & $1(2)$ \\
\hline Withdrawal syndrome & $1(1)$ & $0(0)$ & $1(2)$ \\
\hline Acute respiratory syndrome & $1(1)$ & $0(0)$ & $1(2)$ \\
\hline Rhabdomyolysis & $1(1)$ & $0(0)$ & $1(2)$ \\
\hline Hypersalivation & $1(1)$ & $0(0)$ & $1(2)$ \\
\hline Hemoptysis & $1(1)$ & $0(0)$ & $1(2)$ \\
\hline Hematoma & $1(1)$ & $0(0)$ & $1(2)$ \\
\hline Congestion/hypersecretion & $1(1)$ & $0(0)$ & $1(2)$ \\
\hline Drunkenness & $1(1)$ & $0(0)$ & $1(2)$ \\
\hline Coma (GSC 3) & $1(1)$ & $0(0)$ & $1(2)$ \\
\hline Bradypnea/breathing pause & $1(1)$ & $0(0)$ & $1(2)$ \\
\hline
\end{tabular}


Table 2. Care management of phenethylamine poisoning as reported to the Angers PCC between 2007 and 2013.

\begin{tabular}{ll}
\hline Treatment & n (\%) \\
\hline Sedation and seizure management & $22(21)$ \\
Other symptomatic treatments & $12(11)$ \\
Intubation and assisted ventilation & $10(10)$ \\
Oxygen therapy & $4(4)$ \\
Substitute for plasma/IV fluids & $4(4)$ \\
Decontamination & $3(3)$ \\
Antibiotics & $2(2)$ \\
Hemofiltration/hemodialysis & $2(2)$ \\
External cardiac massage & $2(2)$ \\
Adrenaline & $2(2)$ \\
Analgesic & $1(1)$ \\
\hline
\end{tabular}


Table 3. Analytical data and main symptoms of severe (PSS3) cases of phenethylamine poisonings reported to the Angers PCC between 2007 and 2013.

\begin{tabular}{|c|c|c|c|c|c|}
\hline $\begin{array}{l}\text { Age } \\
/ \text { sex }\end{array}$ & Drug & Analytical data & Symptoms & $\begin{array}{l}\text { Associated } \\
\text { drugs }\end{array}$ & $\begin{array}{l}\text { Final } \\
\text { outcome }\end{array}$ \\
\hline $22 / \mathrm{M}$ & MDMA & $\begin{array}{l}\text { Urine: MDMA > } 8000 \mu \mathrm{g} / \mathrm{L} ; \\
\text { MDA }=63 \mu \mathrm{g} / \mathrm{L} \\
\text { Blood: } \mathrm{MDMA}=160 \mu \mathrm{g} / \mathrm{L}\end{array}$ & $\begin{array}{l}\text { Bradypnea, cyanosis, dehydration, } \\
\text { hypersecretion, hallucinations, } \\
\text { hepatic cytolysis, hypertonia, } \\
\text { hypothermia, acute renal failure, } \\
\text { metabolic and gas acidosis, myosis, } \\
\text { coma (GSC 10), tachycardia, cardiac } \\
\text { rhythm trouble, rhabdomyolysis }\end{array}$ & $\begin{array}{l}\text { Cannabis } \\
\text { Alcohol } \\
\text { Heroine } \\
\text { Acetaminophen }\end{array}$ & Recovery \\
\hline 23/M & AMPH & $\begin{array}{l}\text { Urine: } A M P H=1640 \mu \mathrm{g} / \mathrm{L}\left(\mathrm{D} 1^{\mathrm{a}}\right) \\
\text { Blood: } A M P H=40 \mu \mathrm{g} / \mathrm{L}\left(\mathrm{D} 0^{\mathrm{a}}\right)- \\
\text { negative }\left(\mathrm{D} 1^{\mathrm{a}}\right)\end{array}$ & $\begin{array}{l}\text { Hematoma, hypotonia, mydriasis, } \\
\text { coma (GSC 9), disorientation, cardiac } \\
\text { arrest }\end{array}$ & $\begin{array}{l}\text { Cannabis } \\
\text { Heroine }\end{array}$ & Sequelae \\
\hline 21/M & AMPH & Urine: positive for AMPH & $\begin{array}{l}\text { Seizures, metabolic acidosis, } \\
\text { restlessness }\end{array}$ & Cannabis & Recovery \\
\hline 25/M & MDMA & Negative & $\begin{array}{l}\text { Anuria, chest pain, hepatitis, acute } \\
\text { renal failure, vomiting, } \\
\text { rhabdomyolysis }\end{array}$ & $\begin{array}{l}\text { Cocaine } \\
\text { Heroine } \\
\text { Methadone }\end{array}$ & Recovery \\
\hline 43/M & MDPV & Urine: $\mathrm{MDPV}=3300 \mu \mathrm{g} / \mathrm{L}$ & Myosis, coma & Oxazepam & Recovery \\
\hline 23/M & AMPH & $\begin{array}{l}\text { Urine: } \\
\text { AMPH }=8500 \mu \mathrm{g} / \mathrm{L}\left(\mathrm{D} 4^{\mathrm{a}}\right), 387 \\
\mu \mathrm{g} / \mathrm{L}(\mathrm{D} 6) \text { and } 59 \mu \mathrm{g} / \mathrm{L}\left(\mathrm{D} 11^{\mathrm{a}}\right) \\
\text { Blood: amphetamine }=65 \mu \mathrm{g} / \mathrm{L} \\
\left(\mathrm{D} 4^{\mathrm{a}}\right) \text { and then }<\mathrm{LOD}^{\mathrm{b}}\end{array}$ & $\begin{array}{l}\text { Circulatory shock, cyanosis, } \\
\text { haemoptysis, gas acidosis, acute } \\
\text { respiratory syndrome }\end{array}$ & & Recovery \\
\hline $37 / \mathrm{F}$ & MDMA & Positive & $\begin{array}{l}\text { Anuria, seizures, dehydration, } \\
\text { hepatitis, acute renal failure, coma } \\
\text { (GSC 8), memory issues }\end{array}$ & Cannabis & Sequelae \\
\hline 20/M & AMPH & Positive & $\begin{array}{l}\text { Cardiac failure, tachycardia, low } \\
\text { blood pressure, vomiting }\end{array}$ & & Recovery \\
\hline $23 / \mathrm{F}$ & MDMA & Blood: MDMA $23 \mu \mathrm{g} / \mathrm{L}$ & Memory issues & Alcohol & Recovery \\
\hline
\end{tabular}

${ }^{\mathrm{a}}$ Day after drug consumption

${ }^{\mathrm{b}}$ Limit of detection 
<smiles>CNC(C)Cc1ccc2c(c1)OCO2</smiles><smiles>[R]CNC([R])C([R])c1c([R2])c([R3])c([R4])c([R])c1[R]</smiles><smiles>NCCc1ccccc1</smiles>
phenethylamine<smiles>CCCCCCCCC(C)NC</smiles><smiles>[R4]c1cc(OC)c(CCN)cc1OC</smiles><smiles>[R3]c1cc(OC)c(CC(C)N)cc1OC</smiles><smiles>CC(N)Cc1c2ccoc2cc2ccoc12</smiles>

(3) $2 \mathrm{C}$ series

(5) Bromo-Dragonfly<smiles>[R4]c1cc(OC)c(CCNCc2ccccc2OC)cc1OC</smiles> 


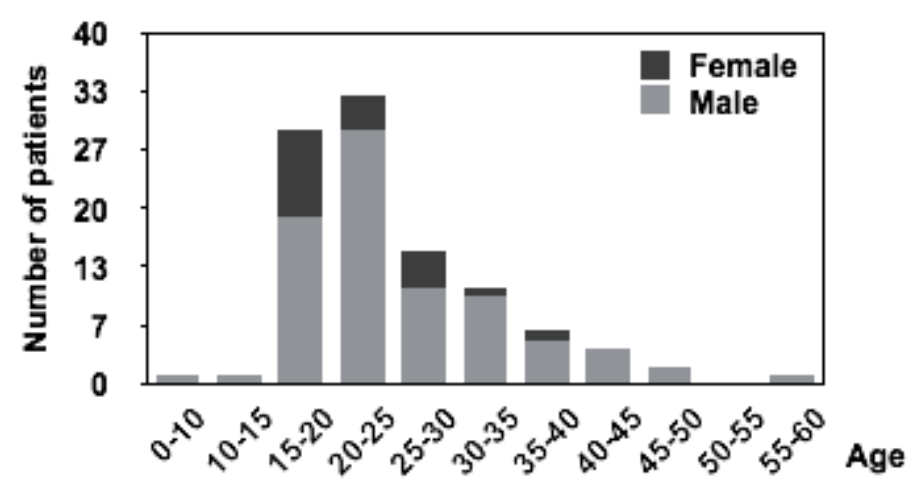

Page 31 of 37 


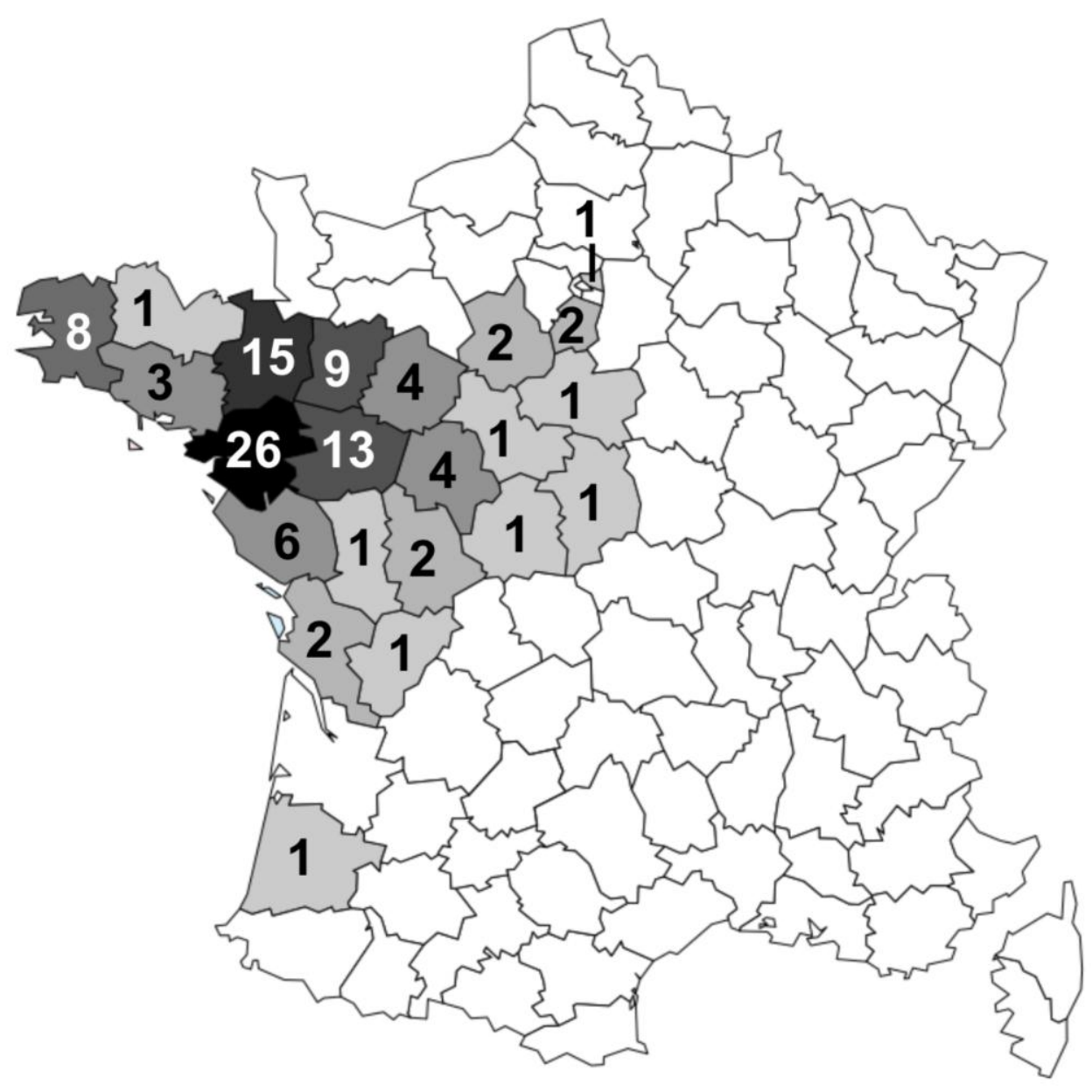




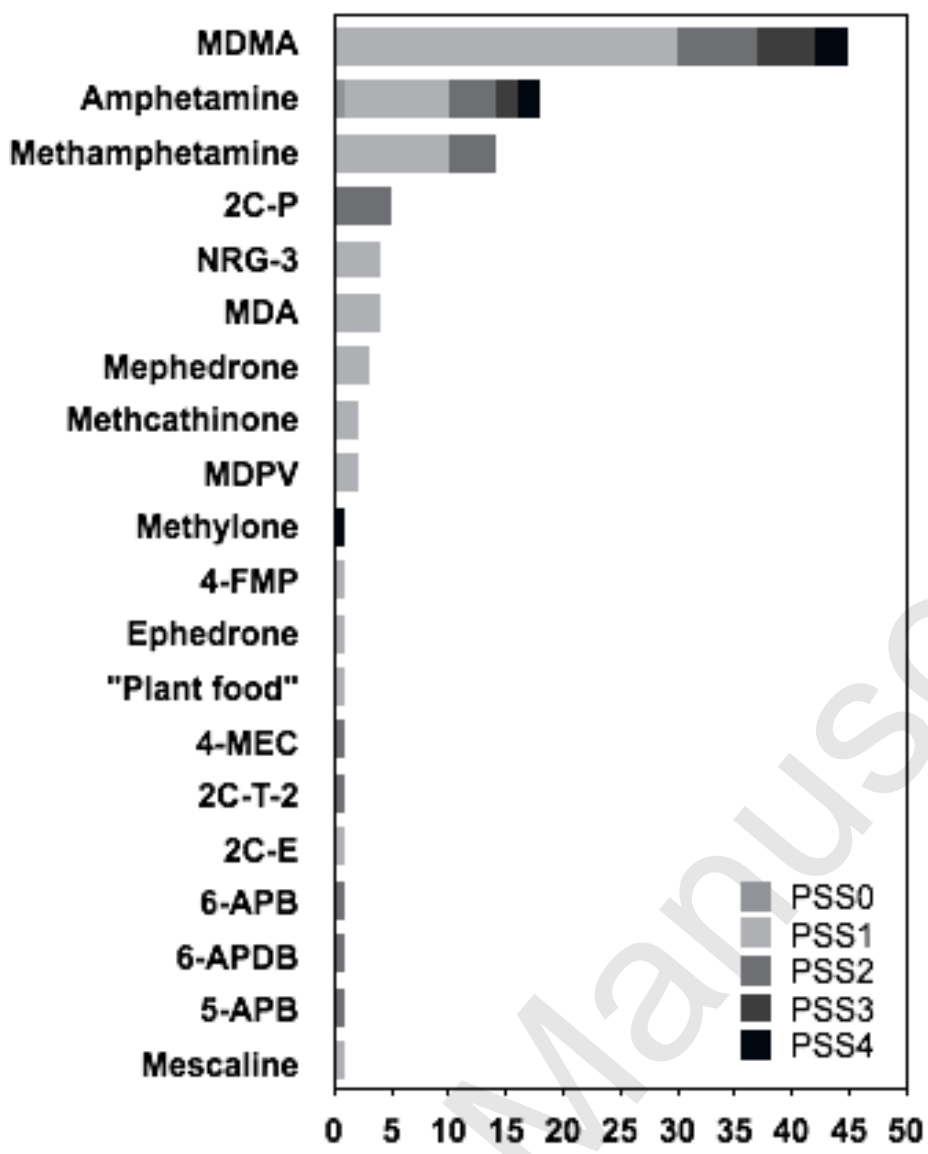




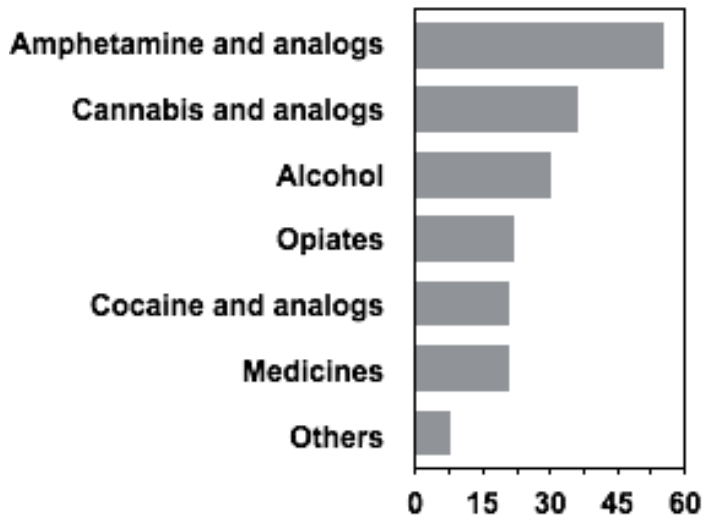




\section{Conflict of interest}

All authors declare that there are no conflicts of interest. 


\section{Contributors}

Authors Gaël Le Roux and David Boels designed the study. Authors David Boels, Chloé Bruneau, Marie Bretaudeau-Deguigne and Patrick Harry collected cases of the Emergency Answering Service. Authors Alain Turcant and Bénédicte Lelièvre shared their analytical skills for toxicological investigations. Author Gaël Le Roux wrote drafts of the manuscript, which were subsequently circulated to all authors for their comments, critiques and suggestions. All authors contributed to and approved the final manuscript. 


\section{Highlights:}

We analyzed 105 cases of phenethylamine poisoning reported to our poison control center.

MDMA, amphetamine and methamphetamine were the most represented drugs.

Psychiatric, cardiovascular or neurological disorders were the most frequent symptoms.

Toxicological confirmation was performed in more than half of patients.

Exposure was severe in nine cases and fatal in five cases. 